\title{
LA DISCAPACIDAD NO LOS LIMITA, NO LO HAGAS TÚ
}

\author{
Claudia Lilia Gallegos García \\ Doctora en Educación \\ Universidad Juárez Autónoma de Tabasco \\ claliga73@hotmail.com
}

Ser docente implica compromiso, dedicación y formación continua para afrontar todos los retos que se van presentando en el quehacer educativo y dar las soluciones adecuadas a cada uno de ellos.

En mis dieciocho años de experiencia en el nivel superior, las dificultades académicas que se han presentado, han sido resueltas de manera satisfactoria y sin contratiempo alguno, sin embargo, jamás hubiera pasado por mi mente vivir uno de los desafíos más grandes en mi vida profesional: tener como alumna a una joven invidente.

En un primer momento el impacto fue muy fuerte, la incertidumbre y preocupación atormentaban mis pensamientos, era un verdadero reto para mí tanto a nivel profesional como personal. Los primeros días me sentía ansiosa y hasta cierto punto desesperada, no poseía los conocimientos necesarios para tratar con personas con discapacidad sensorial.

No obstante, mi vocación docente me impulsó a valorar esta experiencia y transformarla en un nuevo aprendizaje, en lugar de darme por vencida y renunciar a ella.

A partir de la asimilación y aceptación de este reto, inicié la búsqueda de información sobre el trato que una persona ciega debía recibir y, al mismo tiempo, conocer las investigaciones y propuestas que se habían realizado al respecto, así como las estrategias y dinámicas pertinentes para el trabajo áulico. De esta forma pude tomar de esa revisión del estado del arte lo que era factible aplicar en mi entorno.

El acercamiento a un ambiente desconocido para mí fue de gran utilidad, sin embargo, mi vida dio nuevamente un giro cuando la Fundación Ilumina de la Ciudad de México hizo acto de presencia en la Universidad Juárez Autónoma de Tabasco y a través del diplomado Inclusión educativa y social de personas con discapacidad, nos mostró de una manera sensible y clara a los docentes del mundo de los ciegos, sus potencialidades, desafíos, destrezas, habilidades y sobre todo su gran calidad como seres humanos.

Las jornadas fueron intensas, los ejercicios realizados en ellas, nos hicieron vivir momentáneamente como ciegos pues con el fin de realizar algunas actividades, nos cubrían los ojos con antifaces de tela negros, por ejemplo, servirnos el café, salimos del aula, caminamos por el lobby del edificio donde nos encontrábamos, subíamos y bajábamos escaleras. Tenía sentimientos encontrados. En las primeras actividades realizadas con los ojos tapados, la angustia y desesperación afloraron por lo que algunos compañeros claudicaron, se quitaron los antifaces y comentaban que NO podían hacerlo. Su miedo, angustia y desesperación eran más fuertes que ellos; en esos momentos de incertidumbre, comprendí realmente lo que las personas ciegas pueden llegar a sentir y sobre todo a los maestros asistentes, nos sirvió para valorar más nuestras vidas y condición vidente.

Al referirnos a las personas que poseen algún defecto físico lo hacemos mediante el uso de términos como: "persona discapacitada", "persona con capacidades especiales", "cieguitos" o "inválidos", dichas frases o palabras suenan y tienen un efecto despectivo porque si nos alejamos de los eufemismos y nombramos la realidad como corresponde, a las personas que carecen de visión o padecen de alguna dis- 
capacidad física se les denomina personas con discapacidad o ciegos; ésta es la terminología correcta.

En el caso específico de los ciegos, el trato y el vocabulario que se utilice para hablar con ellos debe ser el mismo que se utiliza con todas las personas, es decir, no debemos tener ningún sentimiento de culpa si les hacemos comentarios como: ¿ya viste que no es difícil?, veras que lo lograrás; de igual forma si ellos utilizan frases como: maestra no la vi cuando entró al salón, ayer vi una película o un programa interesante en la televisión.

Raquel $^{1}$

El trabajo que he venido realizando con Raquel desde agosto de 2012 hasta el momento, ha sido en primer lugar, de integración grupal. Es importante que ella sienta que realmente pertenece a un grupo, y sobre todo que es capaz en la medida de sus posibilidades de realizar todas las actividades en el aula.

Recuerdo una ocasión cuando enseñaba vocabulario de las profesiones en italiano, les mostraba tarjetas a los alumnos con la imagen de la profesión y ellos.

Afortunadamente, hoy en día los avances de la ciencia y la tecnología no solo están disponibles para personas videntes, los ciegos reciben un gran beneficio en este sentido. Así, la tifloteconología que hace referencia a la tecnología para ciegos y/o personas con baja visión, las computadoras parlantes son una herramienta indispensable para facilitar el trabajo de los alumnos ciegos; lo mismo que el programa de magnificador Magic y el sistema Jaws for Windows. El magnificador permite al débil visual leer toda la información en la computadora mediante la ampliación de imágenes y textos. Por su parte, Jaws for Windows, permite a los ciegos, convertir textos escritos en audios, escuchar las letras al momento de teclearlas en la computadora y posteriormente hacer revisión

1 Nombre cambiado para preservar la identidad. de lo escrito mediante una voz que les va leyendo todo el documento, los ciegos aprenden comandos para poder acceder a las funciones en sus ordenadores.

Actualmente, Raquel utiliza su computadora para resolver todo lo solicitado, lo guarda en archivos y al final de la clase, lo entrega en un dispositivo USB.

\section{Los compañeros de aula}

Otro de los elementos importantes en la inclusión educativa de personas con discapacidad sensorial, son sin duda alguna los compañeros de clases, ellos juegan un papel importante al igual que el docente, en la integración de los mismos. Raquel ha sido aceptada por sus compañeros desde el primer encuentro que tuvieron con ella, al momento de realizar actividades en parejas o en grupos, la buscan para integrarla a sus equipos. Desde que trabajo con ella, no he presenciado algún acto de discriminación o rechazo por parte del resto del alumnado.

A pesar de todo lo aprendido en el diplomado, de las estrategias y sugerencias recabadas en el estado del arte, falta mucho por hacer, los alumnos con discapacidad sensorial y física ya están inmersos en la educación superior, las circunstancias que enfrentan no son una limitante para lograr una superación personal y profesional. Es de vital importancia que todos los docentes nos preparemos para poder brindarles al igual que los demás alumnos, una educación y formación de calidad. Por otra parte, las instituciones también necesitan realizar ajustes en los programas de estudio y al mismo tiempo en la infraestructura; de esta forma, la estancia y desplazamiento de las personas con discapacidad en las instituciones de educación superior, como es el caso de la Universidad Juárez Autónoma de Tabasco, será placentera y al mismo tiempo las personas con discapacidad sensorial y/o física se sentirán integrados a la sociedad a la que pertenecen. 